\title{
Decoloniality and Enslavism
}

\section{Sabine Broeck \\ ORCID ID: https://orcid.org/0000-0003-3891-8856}

\begin{abstract}
In this article, I propose an overdue connection between the critical concept of decoloniality, and the framework of what I call enslavism, as a term for the human abjective practices of enslavement of Black life during the hundreds of years of the transatlantic slave trade, New World slavery and its ongoing afterlives. It seems to me that much of recent decolonial theory has - beyond making nods to the event of transatlantic slavery - not extensively addressed the specific history and present of enslavist anti-Black violence in its connection to the history of imperial coloniality.
\end{abstract}

Keywords: slavery, imperial coloniality, settler colonialism, enslavism, human abjective practices

\section{Introduction}

In this article, I propose an overdue connection between the critical concept of decoloniality, and the framework of what I call enslavism, as a term for the human abjective practices of enslavement of Black life during the hundreds of years of the transatlantic slave trade, New World slavery and its ongoing afterlives. It seems to me that much of recent decolonial theory has - beyond making nods to the event of transatlantic slavery - not extensively addressed the specific history and present of enslavist anti-Black violence in its connection to the history of imperial coloniality. There seem to be quite separate strands of debates about settler colonialism, as well as strands about post-slavery racism against Black diasporic life. I agree with the current afro-pessimist approach (Wilderson 2010; Sexton 2008; Hartman 2007, if in a different register) to see different structures of violence employed against, respectively, indigenous populations and Black people, a difference not in scale but in quality as one between white human practices of contingent violence occasioned by 


\section{Sabine Broeck}

theft of land and sovereignty, on the one hand, and gratuitous violence against Black life which keeps re-producing 'social death' (Patterson's by now wellestablished term from 2000), on the other. I see the production of Black social death as one of the mainstays of ongoing coloniality - in that it overlaps with white (post)imperial domination, as in the case of South Africa (Maart 2014b). In addition, the embeddedness of gratuitous anti-Black violence at the center of post-Enlightenment Western formations of humanity has to be seen more clearly. I suggest, as the mainstay of ongoing metropolitan regimes of coloniality which critics like Wynter (2005); James (2017); Dussel (1996); Mignolo (2009; 2018); Lewis Gordon (2000; 2007a; 2007b), Jane Gordon (2014) and Trouillot (1995) foreground. Others, who represent a spatially and temporally wide decolonial project, one could say, with respectively different interests and foci - too many to reference here -, have introduced and disseminated important work around the millennial turn, such as de Sousa Santos, Vasquez, Shilliam, Tlostanova, Lugones, Spivak, Tuhiwahi Smith, Bogues, MaldonadoTorres, Bhambra, Randeria, Mbembe, and Martineau.

And recent collections, monographs, and websites exploring the current state of decolonial studies, extensive bibliographies that may be fruitfully explored, include, Broeck \& Junker (2014); Jackson, Manthalu \& Waghid (2017); Tamdgigi et al. (2015); Stingl, Mignolo \& Walsh (2015); Dey (2019); Rivas-Triana et al. (2017); and Franzki \& Aikins (2010).

At this point, one cannot address this rich cluster of contributions as homogeneously, let alone harmoniously assembled intervention; the field at large has been exploding, and has expanded its reach exponentially over the last few years, as a quick search on academia.edu or other platforms will amply demonstrate. This proliferation is being met with massive ultra-right resistance by actors like the AFD (an extreme-right party now present in the German Bundestag and on regional and local levels, known for intense connections to the fascist militant organisations) as was made manifest by a recent debate in the German parliament where the political right intervened to stop or undermine even those most harmless attempts in German politics to address the history of German colonialism ${ }^{1}$.

${ }^{1}$ Cf. https://www.bundestag.de/dokumente/textarchiv/2020/kw47-dekoloniales-sammlungsgut-

$\underline{\text { 804236?fbclid=IwAR0S_hNG1zge0DbRk5zZ5p_kfE7aykwvayrk71FXc2Uq }}$ dhYGHVpHVQBCjE4 
The debate has developed in the context, most recently, of attempts by the German government - in response to the pressure generated nationally by the restitution of 'human remains' - campaigns and the public debates around the restauration of the Humboldt-Forum in Berlin, and internationally by the legal claims against genocide and for reparations of the Herero and Nama - to change their public tune and to fund decolonising events, research activities, and changes in public space like city locations, streets and museums. One also assumes that these current activities to top-down decolonise in the discursive realm have something to do with a kind of renewed scramble for the African continent, given the rapidly growing influence of China, and the USA, but also of countries like Turkey, in African countries. For a radically anti-colonial reading of this more than problematic context I urgently recommend watching the recorded video of Kenyan writer Yvonne Adhiambo Owuor's keynote address at the controversial conference Colonialism As Shared History: Past and Present, organised by the German government and the German Research Foundation (DFG), in which she scathingly destructs these benevolent ways to re-monopolise the discourse for white Western readings of coloniality's 'entangled' histories.

Cf. https://lisa.gerda-henkel-stiftung.de/sharedhistory_keynote_owuor,

\section{Note on Methodology and Location}

This piece of work, like my most recent publications, comes out of a sustained effort to let myself be addressed by Black epistemology, to become a 'spokento', as it were. It is possible because of the work of contemporary thinkers. Most important among them for my work are the following:

Sylvia Wynter (2003); Orlando Patterson (1985); Toni Morrison (1993); Paul Gilroy (1995): Hortense Spillers (1987); Saidiya Hartman (1997; 2007); Lewis Gordon again (2000; 2007a; 2007b); Charles Mills (1999); Rinaldo Walcott (2014); Fred Moten (2013); Frank Wilderson (2000); Rozena Maart (2014a; 2014b); Kwame Nimako (2011); Katherine Mc Kittrick (2013); Egbert Martina (2014); Grada Kilomba (2008); Françoise Vergès (2004); Nell Painter (1995); Jared Sexton (2008); Brand (2020); Christina Sharpe (2010; 2016); and as earlier presences, Fanon (1970) and Césaire (2001). 


\section{Sabine Broeck}

My scholarly work could not be articulated without engagement with decades of Black intellectual and epistemic labour antecedent to it, and generative of it. In keeping with this trajectory, my article proposes a metacritical look at current discourses and practices of decoloniality that have been activated in the last few years, specifically in the German context which has been, of course connected to and impacted by, the international rise of decoloniality as a critical paradigm to read the global modern world. For reasons of space and time constraints, this article cannot deliver an exhaustive investigation of those discourses; it works by way of an assemblage of notes addressing what I consider paradigmatic discursive instances of my present moment. I conclude with some suggestions as to the urgency of an antienslavist pedagogy for the Humanities. My position is that of a white senior scholar at a North-Western German university, the academic and scientific prerogatives of which have remained anchored in the largely unexamined framework of post-Enlightenment Humanities, and the Natural and Technical Sciences with their inherently white and racist premises unimpeded, even though in the last years, as in other German institutions, post and decolonial interventions have begun to erode the silent understood-ness of Enlightenment conceptions of the world.

As a scholar of the crucial role transatlantic enslavement played for the constitution of contemporary European societies, not just for the USA, the Caribbean region and the African continent, with my work, I wanted to contribute to an overdue critique of the systemic agnotology which has kept anti-Black enslavement safely ensconced in subfields of historiography, instead of acknowledging the political, cultural and social function transatlantic enslavement, inseparable from modernity's coloniality, assumed for European societies. We live globally, to paraphrase Hartman (2007), in the future slavery has made.

\section{Bottom-up Struggle versus Top-down 'Decolonisation'}

Decolonial initiatives, Black German and Black migrant intellectuals, scholars and activists, as well as white supporters in universities, museums, and political environments) have as of late speedily gained traction in German mainstream media and politics, and have managed to overcome the obscurity to which they used to be relegated, in a society keeping itself over-determined by the historic responsibility of coming to terms with the Shoah, at the expense 
of taking any account of the history and culture of German coloniality. They have thus managed to draw attention - if aggressively contested by conservatives and the new right-wing populist extremist, to hitherto almost completely suppressed parts of German history, most prominently the German genocidal war in Namibia, and the political campaigns for financial reparations to its victims and their descendants, but also the cultural activism around the repatriation of so-called 'human remains' from German ethnological collections, or the overdue critique of the coloniality of artefact collections in German museums and art institutions. This wider context has been created by political and intellectual pressure generated in Germany by Afro-European and international Black diaspora communities' critical rearticulations of European post-Enlightenment hubris.

Much of this work has begun to circulate on websites (cf. the excellent critical contributions by Martina 2014) as well as in a number of recent publications in German ${ }^{2}$. For texts on Black Europe published in English, readers may consult Opitz et al. (1992), also Hesse, Pitts, Wekker (2009) as well as Florvil and Plumly (2018).

I also refer readers to a number of online interventions:

https://advocate-europe.eu/stories/when-will-eu-put-black-europeanspolitical-agenda/,https://www.europarl.europa.eu/news/de/pressroom/20190321IPR32133/end-racist-discrimination-against-afro-europeanpeople-in-the-eu;

http://isdonline.de/projekte/;

www.berlin-postkolonial.de;

www.hamburg-postkolonial.de/willkommen.html;

https://www.eoto-archiv.de/leadership-und-advocacy/\#netzwerk-schwarzerforschender; https://decolonizationinaction.com/2019/10/11/episode-1-part-2decolonizing-berlin/;

${ }^{2}$ See Florvil (2018) for a more extensive bibliography. 


\section{Sabine Broeck}

https://www.institut-fuer-menschenrechte.de/themen/schutz-vorrassismus/int-dekade-fuer-menschen-afrikanischer-abstammung/.

Thus, the white German liberal public, backed by recent decolonial historiography appearing in leaps and bounds, has begun to take notice of, and steps against the silencing of German colonial history and colonialist culture in the metropolis.

Cf. https://zeitgeschichte-online.de/thema/dekolonisierung-undpostkoloniale-gesellschaften-afrika; http://www.kulturratshop.de/Kolonialismus-Debatte-Aus-Politik-Kultur-17.

Not all of this work has appeared in English. Cf. Zantop et al. (1998); Osterhammel (2000); Hund (2011); as well as Naranch \& Eley (2014), and most prominently in the German contemporary context, the recent work and activism of German historian Jürgen Zimmerer (2014).

https://www.geschichte.unihamburg.de/arbeitsbereiche/globalgeschichte/fors chung/forschungsstelle-hamburgs-postkoloniales-erbe.html

In Bremen, the town where I live and work, this accelerating discourse has led to a number of exhibitions, events, public workshops and political interventions, which has been initiated and supported by Black-led grass roots activist groups like. See for instance, https://www.decolonizebremen.com/;

and,

https://www.rosalux.de/stiftung/projektfoerderung/projekte/projekt/info/718 3/decolonize-bremen-politische-bildung-zu-kolonialen-spuren-rassismusund-widerstand/.

At the same time, it has taken the shape of a top-down discursive process which functions largely to contain post, de- and anti-colonial resistance, energy and intellectual input within the prerogatives of white political control. This political process, organised by the City of Bremen's senate as a series of open forum debates with stakeholders interested in working through, as the media speak has it, the 'legacy' of colonialism, has resulted in an extensive 
proposal to frame future decolonial activities of the city, the university, grassroots groups and other actors.

\section{Cf. https://www.kultur.bremen.de/service/kolonialismus-13508.}

Some years ago, I also used the word 'legacy', which I have come to reject, having realised the transgression involved in appointing violent antiBlack history to a 'legacy' for the Humanities. Euphemistically calling a century-long practice of anti-Black abjection 'our Erbe' (legacy, or inheritance) has moved the public from a ground zero of utterly silencing the history and presence of German colonialism to enthusiastic, high-speed and upbeat confessions of 'our' responsibility for the past as if that would not require any material, social and political cost and a revolutionary end to present day extractive policies vis-à-vis African countries.

This critique, it bears repeating, should not at all be taken as a comment on Black and allied grassroot activist, and intellectual struggles for decolonisation. Quite the contrary, it wants to claim some reservations vis-à-vis all too facile practices of decolonisation in a declarative mode of white benevolence. It is striking, if not surprising, to see the wide array of immigrant communities from the African continent largely absented from this discursive overhaul project to re-invent the City of Bremen as a host and motor of decoloniality. This, as one may safely assume, has reasons not only in language difficulties, which isolate those communities, and in their insecure legal status as refugees, or as paper-holders of only temporarily granted staying permits, which prevents them from participation in civic action, but also in anti-Black racism of a mainstream white community who cannot even see them as agents of change in their own right. What these injunctions infer is the challenge to theoretically think through critical decoloniality in the tension between the eventual arrival of white mainstream interest in 'the issue' of the colonial German past and the growing, if rarely acknowledged pressure on the liberal mainstream by African, Afro-European and Black diasporic agents and discourses. Even though there are a handful of exceptions, as in the recent massive interest in Felwine Sarr's (2016) intervention against Beutekunst (looted artefacts) in European institutions, the default option is still and again to re-create and disseminate decolonial consciousness as somewhat of a white virgin birth (cf. Sarr's recent contribution to the decoloniality debate).

Thus, as another recent addition to these discourses, the highly regard- 


\section{Sabine Broeck}

ed and visible German weekly DIE ZEIT produced a special feature issue on German Colonialism (cf. Werner 2019) which assembles state-of-the art German scholarship in the field. Except for a one-page contribution, aptly subtitled 'Zwischenruf' (interjection) by an Afro-European journalist and curator, Arlette-Louise Ndakoze (2019) in this 40-page dossier about the history of German colonialism, and for an article by a Chinese author, all the contributions are by German historians. Ndakoze angrily protests against ongoing European racism in the guise of mythically employed European 'Humanität' (the ideal of lived and shared humanness). With the above exceptions, the magazine consists of white-authored scholarly articles on various facets of German colonial involvements and their present afterlives which altogether manage to create the impression of white discovery of these issues. This issue seems to be one of the visible results of the pressure campaign which German historian Zimmerer and his research cluster at the University of Hamburg has mounted within academic circles, and beyond, in liberal media. However, there is not a single mention of Black diasporic scholarship and activism dating back to the early days of transatlantic enslavement which has laboured and struggled for anti-enslavist and decolonial epistemologies for centuries, from the freedom narratives (traditionally called 'slave'- narratives) to the 20th century thinkers ranging from James to Wynter, from Williams through Rodney to Biko and recently to contemporary academic interventions like the present collection.

Thus, the issue creates a bitter aftertaste in the mouth of this reader at least: are we to believe that decolonialism is, with a guilty twist, no longer the white man's (and white woman's) burden but their self-owned achievement? In the same vein, and reminding at least this reader of self-congratulatory British events and publications that, in 2007, celebrated 200 years of the abolition of slavery as a white achievement, the hundreds of years of the transatlantic enslavement trade and economy appear in Europa zwischen Kolonialismus und Dekolonisierung, the official publication of the German Bundeszentrale für Politische Bildung, compressed into the 'transnational event' of the trade's legal abolition, and focused on abolition campaigns as proof, that 'the debate about participation, equality and human rights had achieved global dimensions in the $19^{\text {th }}$ century' (Metzler 2018:11).

Paraphrasing Rosalind Morris, Black life here becomes 'the site of primal conflicts and violence and of radical social justice', due to a white 'desire for the possibility of a forgiveness of colonial violence' (Morris 2019). 
Black life, in the similar approach of Nsabimana (2019), excluded 'from the category of the human for so long and whose exclusion legitimated the institutions of slavery, now come back as the bearers of the human, as the shining representatives of its most exemplary promise: forgiveness' (Nsabimana). She names this 'moral racialised extractivism' (Nsabimana). This is an apt phrasing for many of the white impulses driving the current wave of decolonisation debates, which seem to dream of coloniality as a legacy transcendable by way of benevolent discursive relations. The question I am thinking through is: how are these practices of framing decolonial discourse as an issue of a white recreation of self-consciousness connected to the anti-Black violence of what I call enslavism?

There is epistemic anti-Black violence at work in the extensive denial of discursive leadership and authority which has muted Black diasporic interventions other than as ethnographic spectacles of suffering, which Hartman (1997) has named 'scenes of subjection' in the continuation of slavery's accumulation and fungibility of Black life for human societies. How endemic these processes of epistemic appropriation are for white scholars is something I myself had to realise by way of a sharp critique by Afro-German scholars and activists who rightfully criticised our work at Bremen, in INPUTS and in CAAR (Collegium for African American Research). They objected massively to us illegitimately calling our research group - composed of white PhD and post-doctoral students - 'Black Studies', and bolstering white academics' careers in research of the Black diaspora, instead of pushing for anti-white supremacist change by way of strategic hiring/supporting of Black people in the academic body. The group was disbanded. At this point in time, there is still not a single Black Studies degree programme nor a department in any German university. At the point of writing this, the Berlinbased organisation EOTO has begun a campaign for massive changes in the German system of higher education, calling for substantial structural interventions into universities' agendas and for the implementation of Black Studies, and Black knowledges - focused on anti-racist teaching, research, and funding practices.

Methodologically, what follows therefore is a series of notes which represent a work-in-progress combination of previous writing with some observations of decolonial constellations in my local and national environment. These notes are meant to suggest an ensemble of questions much in need of further debate. 


\section{Sabine Broeck}

\section{Decoloniality in Process}

Decoloniality has become the new social media buzz, and it seems as if - from one day to the next - European institutions are eager to admit to their colonial past (if not to their neo-colonial present, necessarily) and to decolonise from the top down. As an overdue response (often not acknowledged as such) to years of widely ignored work of Afro-German individuals and collectives, as well as white and Black postcolonial diasporic initiatives inside and beyond the academy, this version of 'decolonise!' appears to be a kind of white cultural imperative to become better citizens by looking at the legacy of colonialism, as it is being framed now in mainstream media. As such, whilst one need not doubt the emphatically righteous motivation of at least some of those white discourse movers and participants, the driving premise of these top-down decolonisation efforts seems to suggest a form of damage control: to limit the potential threat of resistance and demands by Black people in the here and now for a change in the costly realm of the social and the political. It is the creation of a broad liberal, open discourse on all possible venues, a socalled 'civil forum' policy as in Bremen which creates the illusion of participation and impact, and of a bottom-up surge, because everybody, such is the mantra, will be 'heard'.

'Everybody' involved, in most cases, agents of white civil society have been spurred to action (in the first place) by grassroots communities of Afro-German activism, and some white post-colonial engagement. They then assumed leadership positions within those campaigns almost immediately. As a result of the semi-public debates, there now exists an extensive proposal:

https://www.kultur.bremen.de/service/kolonialismus13508)\%20\%20\%20\%20\%20\%20.e

Such documents are telling in that they predominantly list cultural issues, which may be addressed without allotting much additional financial and/or manpower resources to the so-called decolonisation process. The recommenddations for action include alternative renaming of streets against the colonialist public memory embedded in names like Lüderitz-Strasse, in keeping with Black led campaigns in other German cities

https://www.kolonialismus.uni-hamburg.de/2016/12/01/6-nachwort-joshuakwesi-aikins-diedekolonisierung-des-stadtbildes-strassennamen-zwischenkolonialnostalgie-und-perspektivumkehr/. 
They also suggest a revamping of museum artefacts and expositions. In keeping with the spirit of this state-moderated process the mode of this endeavour is rather upbeat, and connects this recent development, which started in 2016, with an idealised history of responsibility that Bremen has supposedly performed ever since the 1970s. What goes unnoticed in this optimistic narrative of doable top-down decolonisation is the fact that the first wave of anticolonial activity in Bremen in the 1970s, which led to an anticolonial commemorative plaque on the city's colonialist Elephant memorial was the result of a fierce struggle of leftist, anti-imperialist activists, students, leftist university actors and grassroots activists.

\section{Cf. https://www.bremen-sehenswert.de/anti-kolonial-denkmal-elefant.htm}

This local battle supported an international solidarity campaign with the liberation struggle in Namibia, and it was won against the powers that were: a struggle that was shunned and pushed to archival silence by the city's and the university's more recent collective memory.

What also goes unnoticed in this current decolonisation programme is Bremen's long-lasting involvement in slavery and its extensive role in it as an early beneficiary and profiteer of the enslavist plantation economy via their international finance connections, their trade in sugar, in linen for slave clothing, cotton, cocoa and tobacco, and as one of the major enslavist port cities. Thirdly, the process is almost always focused on the past as past. On the part of state-loyal white actors in these campaigns there is no connection made between a critical examination of the so-called colonial 'legacy' and the enslavist racism in discourses, practices and policies of our present.

Effective changes in the racist composition of state systems of discursive and material power and control, as in immigrant legal status, as in schools, universities, museums, media have not been adequately forthcoming, even though a series of proactive measures modelled on the Equal Rights Amendment in the USA might be easily imaginable. Instead everyday antiblackness prevails and different forms of racist violence against non-white Germans, migrants and refugees, including state policing and fascist attacks accelerate. In this context of white benevolence and its flipside, anti-black agnotology and violence, I see the surge of sudden interest in decolonisation - as laudable as it might be compared to its non-existence in mainstream liberal German consciousness until about five years ago - as a massive effort 


\section{Sabine Broeck}

to co-opt actors into a discourse that frames actions like the change of street names from colonial slaughterers to activists/scholars/thinkers or potentates of the Black diaspora as a kind of end result of decolonisation instead of a useful reformist step in the realm of everyday, mundane lives of Black life in Germany, however urgent. Bringing 'everybody' into an open forum, except in rare instances, does not include Black migrants and refugees in a city like Bremen.

As such, this top-down decolonisation stands in a jarring, and quite astounding disconnect to grassroots activities with their demands for better living conditions, health care and immigration status of Black people in Germany as the survivors of the ravages of ongoing colonialist policies of arms' deals, climate destruction, wealth extraction and support of politically degenerated elites. There is now a deluge of discourse, after decades of silence on German colonialism and the massive refusal to accept what many white Germans have seen as a second shaming about the past, mobilised beyond the Shoah, but the problem remains that white breast-beating cannot be a substitute for anti-colonialist politics against anti-Black violence in the present. The current discursive decolonisation push into the mainstream works to the same effect the white women's feminism, gay and queer struggles and other white liberation efforts have achieved in the last few decades, which have successfully 'civilised' the western European white human's image of themselves for some factions of the white populace. The already mentioned Yvonne Owuor succinctly and radically critiqued these discourses in her fierce keynote, culminating in the call to the younger generation of scholars and activists, to destruct the white imperial canon and its manifold reincarnations, reminding us of Césaire`s dictum that white Europe is (and remains) rotten to the core. (cf. Césaire's essay 'Discourse on Colonialism' originally written in 1950).

At present, we witness a struggle between populist right and fascist forces who want unchecked violence and white power back, and the liberals who are willing to accept - on the level of cultural politics - the 'legacy' of colonialism. While this kind of basic acknowledgment of European ravages is of course a step forward from the previously dominant agnotological denial of the past, it remains a limited and also overall bad-faith response because it assigns coloniality to a moral guilt, the acceptance of which will create improved white citizenship in the present and therefore heal the wounds of history in a kind retro-active promise. This approach, however, is at best a 
kind of helpless 'ersatz'-move: it shies away from an acceptance of Black knowledge and authority, calling for an end of the world as we know it. If we follow Fanon, Wynter, Césaire and recent post-Fanonian philosophers and intellectuals, like Wilderson, Gordon, Maart and many others, the human is because the Black is not. That insight requires an analysis of ongoing antiBlack colonialist-capitalist white power in the present tense. It will require white support of struggles against white human politics, economies and military systems that aim far beyond white civil acceptance of ethical guilt for the past. I suggest also to think against ethnography: part of the problem with this 'new' white decoloniality is that - while its theoretical impulses could be and have been mobilised for a critique of modernity as a system of white power, as a critique of humanism, and the state apparatus - such kind of radical mode of critique has all but disappeared from interventions bespeaking an attitude that amounts to a white ethnography of suffering.

The most prominent example of this can be seen in the recent white self-satisfaction widely spread in the 'human remains' campaigns, in which bones are being looked at to clear their former belonging, atrocities are being gauged by numbers of objects in museum collections, and ownership has to be forensically attached to individual sufferers of colonialist interventions because otherwise a recognition of that suffering in material terms is considered impossible. The currency here is white outrage; the collateral benefits of this outrage flow back in forms of kudos to white humanist liberal players (quite comparable to $18^{\text {th }}$ and $19^{\text {th }}$ century white abolition's pornotroping that Wood, Spillers and Hartman, among others, have stridently destructed), thus resulting in a kind of narcissistic ownership of the cruelties of past regimes of knowledge and power.

I am not claiming an easy way out of the conundrum of white recoloniality and constant incorporation into enslavism, at all. However, any posture of white innocence in benefaction, as our Bremen group have learned, needs to be given up. A turn is necessary, away from a documentation of Black suffering (which has become the standard currency in much postcolonial and decolonial practices in higher education) from the point of view of benevolent, proto-abolitionist feeling for the victims of such violence, towards a Blackauthorised, and led critique of the white subject's position whose well-being has been conditioned, and for some people, staked on just such practices of abjection. We need to learn how to go beyond ethnographic benevolence, as well as beyond modish buzz as white European teachers, students, intellect- 


\section{Sabine Broeck}

tuals, and how to practice disloyalty to white abjectorship and its ongoing power. Beyond suggesting this theoretical perspective, I also offer some thoughts on the urgency of decolonial, anti-enslavist transdisciplinary research and institutional pedagogy, because the abjection of Blackness is closely tied - in political, cultural, social, and philosophical terms - to the European politics of white identity, of which the European academic landscape is one of the remaining bastions. In our institutions which regularly draw rather uneven numbers of eager Black European students to instruction, but mostly attract more or less naïve white European students, a researchoriented pedagogy needs to be put in place that, in order to counter antiBlackness, will have to teach white humans to live with the unaccustomed and unexpected urgency of loss, or surrender, of European white entitlement beginning with their ownership of history, culture, and philosophy - which needs to be the prerequisite for anti-racist, and decolonial discourses that respect Black knowledges, on and in Europe, and its academies.

\section{Why Enslavism?}

Black Diaspora Studies have produced a wealth of historiography of EuroAmerican modernity with respect to the productive function the transatlantic enslavement trade and New World slavery took on in its constitution, development, and constant economic, social, cultural, and philosophical (re)articulation. This relatively recent critical discourse has only of late slowly trickled into adjacent humanities' disciplines and - to a surprisingly hesitant degree - into European philosophy, and critical theory. Thus, even though New World enslavement as an object of historiography has become one of among the best-researched phenomena of the Western world, other disciplines have been largely resistant to engage the connection between enslavement, modernity's Enlightenment, and its transatlantic history. By way of carefully maintained disciplinary boundaries, an examination of this connection has hardly reached beyond scattered admissions of modernity's so-called paradox. A transdisciplinary field able to address the manifold political, cultural, and epistemic questions arising from an observation of this intricate interdependency, beyond national canons and boundaries marked by Area Studies and their linguistic limitations, still awaits its realisation. Moreover, in order to critique the durable nexus of transatlantic enslavement practices and discourses, and not keep 'slavery' safely entombed in the Humanities' 
archives as deplorable events in the past, we need a term; a term that puts theoretical-critical thinking about modernity as a regime of slavery (to turn Hartman upside down, who amply discusses slavery as a regime of modernity in Lose Your Mother) on an 'equal footing' with established generalising critical terms as anti-semitism, racism, colonialism that allow us to see structures, patterns, and power systems, instead of singular and isolated events.

That kind of term, and I suggest here to say enslavism, will make it possible to criticise a structure and a set of discourses and practices embedded in the 'afterlife' of slavery, to say it with Hartman, again. It is a telling fact that humanist education, including recent so-called avant-garde theory, has so utterly abjected modern transatlantic enslavement from its purview to not even have a generalisable term for it. Slavery, as a term descriptive of a limited temporal and spatial sequence, at best, relegates the practice of enslavement to the realm of a phenomenological particular which may or may not be included in versions of history. If retrievable at all, then it functions again only as event, as having come and gone, not as a structure-generative systematic practice, including its genealogical function; as object of historiography that is, which is by definition, as a string of particulars, not able to generate metacritical, epistemic potential. We have the concept of militarism, so we can theorise wars. Without that frame which then points research to generalisable insight into patterns of imperial designs, capital investments, technological destruction, psychology of war, and other components of war-making, particular instances of war, say, Vietnam, Iraq, Afghanistan, would not be theorisable. We have been able to theorise colonialism as a practice of subjecttion, exploitation, and dominance in the modern arsenal of European power, beyond its various particular instantiations in and by respective countries, because we have a term, even though it had to be re-appropriated from imperial historiography critically and agonistically. Slavery, by contrast, exists in the Western intellectual critical imaginary only as an isolated event, since our very language has axed it from our inner and outer worlds of critical thought.

The 'event' can be described, and historiography, at this point, fills libraries, but it does not translate into a cause for and lever of theorisation, and that is not happenstance, but has method, and purpose. The humanist white subject has been moved to remember, address, articulate, empathise with, rejoice in, question the brutality of, and elicit other particularly emotional responses to the specific situation, to the imagined 'event' of being a slave in slavery. Thus, the image of slavery as traumatic occurrence, situated often 


\section{Sabine Broeck}

beyond the frame of human rational understanding, that limit event - in an act of perverse theft - has given metaphorical heft to modern and postmodern protest against white human suffering and bondage. The idea of slavery as 'event,' and of the slave as a generic, naturalised term for a being held in slavery, however, has never put the white subject's practice of forcing Black being into enslavement and/or of parasitically profiting on any conceivable level from Black abjection, sustained for centuries, on the agenda. On the contrary, the enlightened outrage at the event of slavery has served to screen perpetual white practices of enslavement off from view.

There is a second severe problem with non-generalisability: the event may elicit only affect vis-à-vis the victimised - as ad hoc white pity, terror, or revulsion - meaning white responses to slavery are all still in the realm of Christian emotions, have never passed beyond the abolitionist empathy Marcus Wood has so adroitly deconstructed (Wood). Moreover, the event of slavery, as such, always remains the isolated disembodied entity apart from, outside the white subject's abjectivising agency on and against Black being, that which does not and cannot speak about the white subject's active role in the very production of abjection. In Western white modes of thinking, the making of slavery into an event has thus successfully pre-empted theoretical cognition, as well as epistemic leverage.

Enslavism as a term, as a horizon of common reference from disciplines as varied as History, Philosophy, Modern Literatures, Cultural Anthropology, Law, and Social and Political Sciences, could also facilitate the necessary transdisciplinary research and pedagogy we urgently have to put in place. This is particularly urgent for the European academy, still a bastion of white subjectivity, where the humanities have been drained towards remaining atoms of individual de-colonial, de-enslavist scholars working away in isolation at their institutes, never commanding enough critical mass to garner attention and possible support of the national and supranational research funding apparatuses, and not willing to dilute their own research to the point of non-recognisability in research networks with positivist, presentist, philological, or other idealist multi-, inter-, and even some decolonial agendas, which disconnect their critique of Western subjugation of Indigenous populations and the ravages of their lands and resources from a systemic critique of white power, the mechanics of which were forged, tested, written and rewritten, mobilised and legitimised by and in enslavism's historically founding practice of Black enslavement. 


\section{Beyond Disciplines: Toward a Hermeneutics of Absence and a Pedagogy of the Trace}

Such necessary transdisciplinarity would require a hermeneutic of absence and a pedagogy of the trace (Broeck 2013). In my own work I have addressed the impact of modern enslavism in those areas that more classical transatlantic 'slave'-trade and New World slavery historiography has either not extensively addressed, or which has been silenced. Beginning with my very first questions, for example, of John Locke's philosophy, the history of gardening, the implication of gender in enslavism, or the overall denial of interracial contact in Europe, going through the regimes of modern enslavism suppressed in 19th and $20^{\text {th }}$ century theories of liberation, and ending up, literally, in the German hinterland of enslavism, in a project to assess the impact of enslavement and the 'slave'-trade on the city of Bremen this hermeneutic of absence has brought me up against the confines of established methodologies, research, and dissemination.

\section{Cf. https://urbanpolitical.podigee.io/39-hinterlands slavery),}

Ongoing constraints of disciplinarity within the academy's subdivided humanities serve to prevent the creation and pursuit of research questions and teaching curricula which lie outside the realms of national, and/or disciplinary purviews. This is particularly true with respect to producing an overdue durable epistemology of enslavism even though in very recent years individual scholars have, as renegades to their disciplines, made advances towards more interdisciplinary and transnational methodologies. However, the results of research on modern enslavement in (cultural) historiography, metropolitan ethnography, historical sociology, philosophy, or other pertinent disciplines oftentimes fall entirely outside the teachable agendas and remain all too marginal to the canons the academy has created. This, then, becomes a massive problem for the dissemination of knowledge, and thus for a necessary generalisation and pedagogical availability of this epistemology of enslavism. Heavily indebted to Toni Morrison's Playing in the Dark, I argue therefore for practices of reading and argumentation, which necessarily run counter to the canonical positivism of the disciplinary archive. I want to think about early modern enslavism as that which if one could do something like a socio-psycho-gram of white capitalist empowerment - needs to be analysed as the major propeller of modern capitalist mental and psychic 


\section{Sabine Broeck}

constituencies. If commodification and propertisation, the learning, grasping, and materialising of the world as ownable have been generally acknowledged as the characteristics of (post)modern capitalist society, then the white abjection of Blackness, the violent making of 'thing beings,' of package-able, shippable, transportable, and possess-able and as such usable, itemisable, and fungible bodily entities was its constitutive practice.

As the primary site of financial networking, crediting, speculation, insuring, of profit and calculation - as we know most graphically from Ian Baucom's Specters of the Atlantic: Finance Capital, Slavery and the Philosophy of History - the practice of enslavism must also be considered as the primary psychosocial and cultural, collective, and individual training site for capitalist white human sociability. To learn - directly and indirectly - how to commodify an always already resistant being needs to be considered the primary threshold exercise for the modern human to become, to empower him/herself as subject. If human society could achieve that kind of transport and handling (in the physical and metaphorical sense) of more than ten million sentient beings as things, and then could manage to abject this practice successfully from a collective memory of the history of human freedom, it must have passed the test of its own emerging system's demands in the most generic way, and nothing could stop that sociability from further world commodification. This must be considered as the founding practice of the European human subject: the global transactioning of a shippable sentient species consisting of Black people. This insight begs to be much more consistently incorporated into many of the local decolonial campaigns that have developed over the last decade, including the one in Bremen I have discussed above. There is a history of Bremen's massive involvement in and profiteering - in economic, political and social terms - from the Black transatlantic enslavement in the late 17 th and 18 th century waiting to be written, which obviously predates, and over determines the colonialist structures and policies of the $19^{\text {th }}$ century, and which have shaped Bremen's might and wealth as a city, as well as that of individual families still among the powers-that-be (Beckert 2014). Recent activities against the shamelessly anti-black public self-representation of the Bremer Baumwollbörse to promote the international cotton industry have put this history on the agenda, once more, and initiatives like Decolonize Bremen, and the newly founded Black Community Foundation will not let Bremen's political and economic elites off the hook. 
Cf. https://taz.de/Bloss-keine-Geschichte/!5716162/ ; and https://www.facebook.com/blackcommunityfoundationbremen/

Enslavement differs fundamentally from other traditions of human bondage; it entailed not only Black death, it also created the globally negotiable, transferable and competitive profitability, for the human, of Black social death in a generative way. The crucial difference between, say, warlords that kept prisoners as slaves on their grounds, and the transatlantic modern production of social death was the achievement of an abstraction of non-personalised property, item mobility and thus global marketisation, and the capitalist inheritability of social death. One could, as a human, inherit social death as capital - financially and otherwise, directly and indirectly - as one could inherit other forms of wealth, which of course entailed a constant and structural reproduce-ability of Black socially dead sentient beings. I am interested in finding out what capacities the human, as a group, trained him/herself to exert, to be able to carry out such a historically crucial endeavour. What needs to be stressed in this context is the structural impasse of comparison, the impossibility of analogy, between modern enslavement and forms of colonial, and/ or patriarchal and classist subjugation, domination, or conquest of 'the Other' by which a prior humanity of population groups was called into question, and suppressed (Wilderson 2010). That impasse lies in the purposeful and concerted production of accumulation and fungibility to use Hartman's (1997) terms again, of Blackness as something which categorically lies outside the realm of the human, without land, without gender, without a position within the nexus of free labour and capital, an enforced state of sentience next to the human world without a relation to and within it. It lies in practices of abstract and concrete marketable creation of Black serviceable flesh, as Spillers has argued. That impasse worked in enslavement, as well as it has been working in its afterlife. Thingification and the itemisation of Black life as fungible for whatever only seemingly contradictory purposes suits the human world as we know it, is not a thing of the past; it lives on as enslavism.

If one acknowledges enslavism as a white supra-individual practice, what has it meant for white European empowerment, not just in the economic, political, or social sense, but also in the psycho-cultural, and psycho-historical sense? The problem is how to figure that out in retrospect, particularly, if it has functioned as one of the best kept inner sanctums of white (postmodern) 


\section{Sabine Broeck}

consciousness. What we need is a psychoanalysis of the meaning of abjectification (in the sense of the race-fiction based itemisation, and the absenting of human relationality for Black sentient beings) for the white European subject who has used the very results of those practices of abjectification, perversely, as the threatening border of their own entitlement to self-possession. Thus, the most ubiquitous European post-Enlightenment liberation metaphors: 'We shall never, never, be slaves!' or 'I am not your n---!' mark that white horizon precisely. What I mean to get at is the challenge to think about white self-possession as trained and (ac)knowledged not only in a process of defense and advance against feudal interpellation by the powers of the aristocracy and church rule, that is as a cluster of ideologies emblematising the European subject's liberation from overwhelming and restrictive powers - which translates in the 19th and 20th century into further rebellions against subjectivation by the state, the factory, patriarchal power, and the tyranny of the symbolic. Instead, from an anti-enslavist perspective, these discourses and practices become visible as acquired, and trained and drilled into collective memory as the collective direct and indirect production of Black social death.

\section{Suggestion: Protocols of White Abjectorship}

From here one can move back to the contemporary Black social and civil death that has been produced by the European subject as a late consequence of this kind of abjectorship. Active mainstream ideology these days, ranging in its proclamations from leftists and liberal perspectives through many factions in European white feminism way over to the advocates of the political right, hinges on the imperative to defend Europeanness - culturally, socially, economically, politically, and for some, by various means of warfare - against the perceived threats of Blackness. My point, on the contrary, requires learning to read Europe as the afterlife of enslavism, and thus its internal fictions and practices as always already rotten to the core. The production of movable thingness re-occurs in the Mediterranean today: a new, necropolitical entity has been put, in the most literal sense, into circulation: crucially not a recognised Other to the European self, the 'it,' the drowned Black, is entirely abjected by the categories of European white subjectivity: a transportable, politically and economically usable, but also dispose-able selfgenerative item. 
The Black migrant, both in the metropolises and in the hinterlands, has been denied any dwelling in the realm of 'difference,' and 'otherness' (postcolonialism's key signifiers) but has become registered only as abandonable item-ness. We need a language to talk about the material, political, and cultural interests of the postmodern European subject in this white production and circulation of the Black migrant's social and civil death: to interrupt the white gaze on pitiful suffering, even to disturb the waves of spectacular white media empathy, washing up when things get all too obviously horrible for Black so-called illegal fugitives as in the shock and surprise registered in German media at the time of this writing, geared towards the gratuitous brutalisation of homeless Black migrants by the state apparatus in German cities. Instead, it will be necessary to listen to the radical critique of white abjectorship that political representatives of Black diasporic communities have articulated in various venues, yet without substantial echo in the critical academy. The various Black manifestos and catalogues of demands, and reports of struggles like Lampedusa in Hamburg (see Lampedusa 2014), the work of the ISD and EOTO, the wide range of Black feminist interventions (Florvil 2018; 2020) and the Catalogue of Demands by People of African Descent and Black Europeans are not only responses to particular constraints, violent abuses and discrimination. They all rally against the fundamental momentum of white anti-Blackness: the un-humanisation of Black being. Hearing that critique could, as Spillers has phrased it, lead to the production of protocols of white self-disruption within the academic world. This process has been unconditionally demanded by Black critique: to submit to a Black gaze on the white European practices of re-abjection of Black life which have been mechanised, propelled, and organised by state apparatuses, institutions like the university, and the mainstream media. Attention needs to be directed to anti-racist, anti-fascist investigations into the discourses and practices of a white enslavist continuum, which connects seemingly far extreme ends of the political spectrum.

That attention needs to address the dangerous political mainstream populism raging across European metropolitan cities, and the only seemingly random mob and state violence, oftentimes lethal, against dark-skinned migrants all across Europe, including lynch murders in Southern Italian villages, street violence in Moscow, no-go areas for Black Europeans in European cities, and fascist successes in national and regional elections all over Europe. Moreover, FRONTEX policies of Fortress Europe carried out 
with high and prioritised budgets reaching far into African countries, for military cooperation arrangements on the highest level of command need to be battled against. The white media savvy to promote Europe's sanctity against the so-called 'waves of intrusion' from overexploited Black countries needs to be loudly rejected and undermined. In my reading of the situation, without an analysis of white abjectorship and enslavism the structural European violence against Black being cannot become fully cognitive, and decolonisation remains an impaired analytical frame.

\section{References}

Agamben, G. 1998. Homo Sacer: Sovereign Power and Bare Life. HellerRoazen, D. (trans.). Stanford: Stanford University Press.

https://doi.org/10.1515/9780804764025

Agamben, G. 2003. The State of Exception: Der Ausnahmezustand. The

European Graduate School, 2003. http://www.egs.edu/faculty/giorgio-

agamben/videos/the-state-of-exception-der-ausnahmezustand/ 21 July

2014.

Almeida, S. \& S.H. Kumalo 2018. (De)coloniality through Indigeneity:

Deconstructing Calls to Decolonise in the South African and Canadian

University Contexts. Education as Change 22.:1, \#3023, 24 pp.

https://www.upjournals.co.za/index.php/EAC/article/view/3023/pdf

https://doi.org/10.25159/1947-9417/3023

Bhakti, S., M. Bronner \& V. Cantelli, et.al. (eds.) 2018. Mediterranean:

Migrant Crossings. New York: Up Set Press.

Baucom, I. 2005. Specters of the Atlantic: Finance Capital, Slavery, and the

Philosophy of History. Durham: Duke University Press.

https://doi.org/10.1215/9780822387022-006

https://doi.org/10.1215/9780822387022-002

https://doi.org/10.1215/9780822387022-004

Beckert, S. 2014. Empire of Cotton: A Global History. New York: Alfred A. Knopf.

Brand, D. 2020. An Autobiography of the Autobiography of Reading. Edmonton: University of Alberta Press,

Broeck, S. 2013. Lessons for A-Disciplinarity: Some Notes on What Happens to an Americanist When She Takes Slavery Seriously. In Gohrisch, J. \& E. Grünkemeier (eds.): Postcolonial Studies Across the Disciplines. 
Amsterdam: Rodopi.

https://doi.org/10.1163/9789401210027_020

Broeck, S. \& C. Junker (eds.). 2014. Postcoloniality - Decoloniality - Black

Critique: Joints and Fissures. Frankfurt am Main: Campus.

Broeck, S. \& S. Bolaki (eds.) 2015. Audre Lorde's Transnational Legacies.

Amherst: University of Massachusetts Press.

Broeck, S. \& J. Ambroise (eds.). 2015. Black Knowledges/ Black Struggles:

Essays in Critical Epistemology. Liverpool: Liverpool University Press.

https://doi.org/10.5949/liverpool/9781781381724.001.0001

Broeck, S. 2015. 'It's always now' (Beloved). Notes on the Urgency of

Enslavism Theory, and Studies. In Junker, C. \& M. Löffler (eds.): Black

Studies - Paradigm Shifts. Zeitschrift für Anglistik und Amerikanistik

65:2, 131-144. https://doi.org/10.1515/zaa-2017-0016

Broeck, S. 2018. Gender and the Abjection of Blackness. New York: State University of New York Press.

Césaire, A. 2001. Discourse on Colonialism. Pinkham, J. (trans.). New York: Monthly Review Press.

Demand Catalogue by People of African Descent \& Black Europeans 2014. isdonline.de. Initiative Schwarzer Menschen in Deutschland e.V., 13 - 16 Feb. 2014. https://www.enar-eu.org/Demand-Catalogue-for-People-ofAfrican-Descent-and-Black-Europeans

https://www.enar-

eu.org/IMG/pdf/demandcatalogue_pad_be_short_version.pdf

Dey, S. 2019. Different Spaces, Different Voices: A Rendezvous with Decoloniality. Mumbai: Become Shakespeare Press.

Dussel, E. 1996. The Underside of Modernity: Apel, Ricoeur, Rorty, Taylor, and the Philosophy of Liberation. New York: Humanity Books.

Fanon, F. [1952] 1970. Black Skin, White Masks. London: Paladin.

Franzki, H. \& J. Kwesi Aikins 2010. Postkoloniale Studien und kritische Sozialwissenschaft. PROKLA. Zeitschrift für kritische Sozialwissenschaft 158, 40 (158): 9 - 28.

https://doi.org/10.32387/prokla.v40i158.398

Florvil, T. \& V.D. Plumly (eds.) 2018. Rethinking Black German Studies: Approaches, Interventions and Histories. London: Peter Lang.

Florvil, T. 2020. Mobilizing Black Germany: Afro-German Women and the Making of a Transnational Movement. Champaign, Illinois: University of Illinois Press. 
Gilroy, P. 1995. The Black Atlantic: Modernity and Double Consciousness. Cambridge, MA: Harvard University Press.

Gordon, J.A. 2014. Creolizing Political Theory: Reading Rousseau through Fanon. New York: Fordham University Press.

Gordon, L.R. 2000. Existentia Africana: Understanding Africana Existential Thought. New York: Routledge.

Gordon, L.R. 2007. Problematic People and Epistemic Decolonization: Toward the Postcolonial in Africana Political Thought. In Persram, N. (ed.): Postcolonialism and Political Theory. New York: Lexington Books. Gordon, L.R. 2007. Disciplinary Decadence: Living Thought in Trying Times. Boulder: Paradigm Publishers.

Habermas, J. \& J. Derrida 2003. Nach dem Krieg: Die Wiedergeburt Europas. Frankfurter Allgemeine Zeitung 21 May 2003.

Hartman, S. 1997. Scenes of Subjection: Terror, Slavery, and Self-Making in Nineteenth Century America. Oxford: Oxford University Press.

Hartman, S. 2007. Lose Your Mother. A Journey along the Atlantic Slave Route. New York: Farrar, Straus and Giroux.

Hesse, B. 2009. Afterword: Black Europe's Undecidability. In Hine, D.C.,

T.D. Keaton \& S. Small (eds.): Black Europe and the African Diaspora.

Champaign: University of Illinois Press.

Hund, W.D. 2011. Racism and Modernity. Münster: Lit-Verlag.

Jackson, M. 2017. Coloniality, Ontology and the Question of the Posthuman.

New York/ London: Routledge.

https://doi.org/10.4324/9781315686721

James, S. 2017. Indigenous Epistemology Explored through Yoruba Orisha Traditions in the African Diaspora. Women and Therapy 41: 114 - 130.

Kilomba, G. 2008. Plantation Memories. Berlin: Unrast Verlag.

Kojéve, A. [1947] 1980. Introduction to the Reading of Hegel: Lectures on the Phenomenology of Spirit. Bloom, A. (ed.). Nichols, J.H. Jr. (trans.). Ithaca: Cornell University Press.

Lampedusa in Hamburg 2014. Lampedusa in Hamburg - Refugee Protest. http://www.lampedusa-in-hamburg.org

21 July 2014.

Maart, R. 2014a. Decolonizing Gender in the Academy: From Black Power and Black Consciousness to Black Rebellion. In Broeck, S. \& C. Junker (eds.): Postcoloniality - Decoloniality - Black Critique: Joints and Fissures. Frankfurt am Main: Campus. 
Maart, R. 2014. Philosophy Born of Massacres. Marikana, the Theatre of Cruelty: The Killing of the 'Kaffir'. Acta Academia 46,4: 1 - 28. https://journals.ufs.ac.za/index.php/aa/article/view/1470/1447

Manthalu, C.H. \& Y. Waghid (eds.). 2020. Education for Decoloniality and Decolonization in Africa. London/ New York: Palgrave Macmillan. https://doi.org/10.1007/978-3-030-15689-3

PMCid:PMC6509600

Martina, E.A. 2014. Processed Life. http://processedlives.wordpress.com

McKittrick, K. 2013. Plantation Futures. Small Axe 17. 3/ 42: 1 - 15. https://doi.org/10.1215/07990537-2378892

Metzler, G. (ed.). 2018. Europa zwischen Kolonialismus und Dekolonisierung. Informationen zur politischen Bildung 338, 3/2018.

https://www.bpb.de/izpb/280641/europa-zwischen-kolonialismus-unddekolonisierung

Mignolo, W. 2009. Epistemic Disobedience, Independent Thought and Decolonial Freedom. Theory, Culture \& Society 26,7-8: 1-23.

https://doi.org/10.1177/0263276409349275

Mignolo, W. \& C. Walsh (eds.). 2018. On Decolonization: Concepts, Analytics, Praxis. Durham /NC: Duke University Press.

https://doi.org/10.1215/9780822371779

Mills, C. 1999. The Racial Contract. Ithaca: Cornell University Press.

Morris, R. 2019. Reflections on 'Double Exposures'. The Berlin Journal 33, Fall: 71 - 72.

Morrison, T. 1993. Playing in the Dark: Whiteness and the Literary Imagination. New York: Vintage.

Moten, F. (with Harney, S.) (eds.). 2013. The Undercommon: Fugitive Planning and Black Study. New York: Minor Compositions.

Naranch, B. \& G. Eley (eds.). 2014. German Colonialism in a Global Age. Durham: Duke University Press.

https://doi.org/10.1515/9780822376392

Ndakoze, A-L. 2019. Zwischenruf. In Werner, F. (ed.): Die Deutschen und ihre

Kolonien: Das wilhelminische Weltreich 1884 - 1918. (Spezialheft ZEITGeschichte.) Hamburg: Bucerius Verlag.

Nietzsche, F. [1887] 2013. On the Genealogy of Morals. Scarpitti, M.I. (trans.). London: Penguin.

Nimako, K. 2011. The Dutch Atlantic: Slavery, Abolition and Emancipation. London: Pluto Press. 
Nsabimana, N. 2019. Transitional Justice. The Berlin Journal 33, Fall Issue: $72-74$.

Opitz, M., K. Oguntoye \& D. Schultz (eds.). [1986] 1992. Showing our Colors. Afro-German Women Speak Out. Adams, A.V. (trans.). A. Lorde (Foreword.). Amherst, Mass.: The University of Masachusetts Press.

Osterhammel, J. 2000. Sklaverei und die Zivilisation des Westens. München: Carl Friedrich von Siemens Stiftung.

Painter, N. 1995. Soul Murder and Slavery. Waco: Baylor University Press.

Patterson, O. 1985. Slavery and Social Death: A Comparative Study. Cambridge, MA: Harvard University Press.

Pitts, J. 2019. Afropean: Notes from Black Europe. London: Allen Lane.

Rivas-Triana, A., E. Kulers \& G. Cheng (eds.). 2017. Decolonial Lexicon.

Public Anthropology.

https://scholarblogs.emory.edu/publicanthro/2017/11/25/decoloniallexicon/

Sarr, F. 2016. Afrotopia. Paris: Philippe Rey.

Saucier, P.K. \& T. Woods 2014. Ex Aqua. The Mediterranean Basin, Africans on the Move and the Politics of Policing. Theoria 61, 141: 55 - 75. https://doi.org/10.3167/th.2014.6114104

Sexton, J. 2008. Amalgamation Schemes: Antiblackness and the Critique of Multiracialism. Minneapolis: University of Minnesota Press.

Sharpe, C. 2010. Monstrous Intimacies: Making Post-Slavery Subjects.

Durham: Duke University Press.

https://doi.org/10.1515/9780822391524

Sharpe, C. 2016. In the Wake. On Blackness and Being. Durham: Duke University Press. https://doi.org/10.1515/9780822373452

Smallwood, S. 2009. Saltwater Slavery: A Middle Passage from Africa to American Diaspora. Cambridge, MA: Harvard University Press.

Spillers, H. 1987. Mama's Baby, Papa's Maybe: An American Grammar Book.

Diacritics 17,2: 64 - 81.

https://doi.org/10.2307/464747

Stierl, M. 2019. Can Migrants at Sea Be Heard? Discover Society. https://discoversociety.org/2019/11/06/can-migrants-at-sea-be-heard/

Stingl, A. 2015. The Digital Coloniality of Power. London: Lexington Books. Tamdgigi, M. \& C. Boidon \& J. Cohen (eds.). 2015. Decolonizing the University: Practicing Pluriversity. Belmont: Ahead Publishing House. Trouillot, M.R. 1995. Silencing the Past: Power and the Production of History. 
Boston: Beacon Press.

Vergès, F. 2001. L'homme predateur: Ce que nous enseigne l'esclavage sur notre temps. Paris: Edition Albin Michel.

Walcott, R. 2014. The Problem of the Human: Black Ontologies and the 'Coloniality of Our Being'. In Broeck, S. \& C. Junker (eds.): Postcoloniality - Decoloniality - Black Critique: Joints and Fissures. Frankfurt am Main: Campus.

Wekker, G. 2016. White Innocence: Paradoxes of Colonialism and Race.

Durham and London: Duke University Press.

https://doi.org/10.1515/9780822374565

PMid:27478202

Werner, F. (ed.). 2019. Die Deutschen und ihre Kolonien: Das wilhelminische Weltreich 1884 - 1918. (Spezialheft ZEITGeschichte.) Hamburg: Bucerius Verlag.

Wilderson, F.B. 2010. Red, White \& Black: Cinema and the Structure of US Antagonisms. Durham: Duke University Press.

https://doi.org/10.1215/9780822391715

Wood, M. 2002. Slavery, Empathy and Pornography. Oxford: Oxford University Press.

Wynter, S. 2003. Unsettling the Coloniality of Being/ Power/ Truth/ Freedom: Towards the Human, after Man, its Overrepresentation - an Argument. CR: The New Centennial Review 3.3: 25.

https://doi.org/10.1353/ncr.2004.0015

Zantop, S., S. Friedrichsmeyer \& S. Lennox (eds.). 1998. The Imperialist Imagination: German Colonialism and Its Legacy. Ann Arbor, Mich.: University of Michigan Press. https://doi.org/10.3998/mpub.23579

Zimmerer, J. 2015. Humboldt Forum: Das koloniale Vergessen. Blätter für deutsche und internationale Politik Juli.

Sabine Broeck

Professor Emerita University of Bremen

Germany broeck@uni-bremen.de 